\title{
Methodical Tools of Philological Urbanistics
}

Gulnara Sejlbekovna Suyunova

Olga Konstantinovna Adryuchshenko

Lyudmila Erbulatovna Tokatova

Ekaterina Petrovna Garanina

Pavlodar State Pedagogical University, 60 Mira St., Pavlodar, 140 000, Kazakhstan; Email: olga_pav_pgpi@mail.ru

\author{
Doi:10.5901/mjss.2015.v6n5p258
}

\section{Abstract}

The research is devoted to the analysis of the methodological basis of philological urbanistics. The authors trace the history of formation of scientific problems of urbanistics and analyze trends in the study of the city as an object of research. The article provides a detailed analysis of linguistic methods in a comparatively new direction - philological urbanistics. The possibilities of applying general scientific methods and methods of linguistic research in linguo-communicative environment of the city have been described. Special attention is paid to the perspectives of new approaches to the study of the city, in particular, from the standpoint of general cultural city landscape studies.

Keywords: urbanistics, philology, research methods, linguistics.

\section{Introduction}

The phenomenon of the city is the subject of research for specialists in various branches of knowledge. In the modern period, linguistic, social, economic, environmental, demographic, philosophical, political, historical, and cultural aspects of the city are being actively studied.

Study of the cities phenomenon is very important, since the cities were and are social and cultural centers with their administrative practices, public life organization and the specific composition of the population and, consequently, unique linguistic processes.

In Kazakhstan, in the course of modernization process, a significant growth of cities and the proportion of the urban population has taken place; currently, three quarters of the population live in cities. Cities continue to rapidly concentrate and integrate new economic activities, high-tech industry, financial, trade and educational services, material, cultural and spiritual values, the infrastructure of foreign trade. New types of cities and their different classifications have appeared. At the same time studies on purely linguistic and communicative problems of the city, a description of extra- and introlinguistic factors affecting linguistic image of the city, in the modern Kazakh linguistics are very few. Various scientific studies available today in the Republic do not provide a systematic and complete understanding of modern linguocommunicative problems of the city.

The city as an object of research attracts increasing attention of the representatives of different areas of scientific knowledge: philologists, historians, sociologists, political analysts, philosophers, economists, geographers and others.

One of the most important aspects in the history of cities study is the research in the field of everyday life. The history of everyday life has an independent scientific value and is important in the context of a more general problem: the development of regional models of culture and language of the city, the study of the specificity and mechanism of their functioning at different social and intellectual levels. Daily life encompasses the entire living environment of man, the scope of direct consumption, satisfaction of the material and spiritual needs, the associated customs, rituals, behaviors, ideas, and habits. A related reflection analysis in the language of these processes is extremely promising.

In light of this, philological research of cities can more fully characterize the entire phenomenon of the city and urban life; it is a productive area in the world and domestic urban planning.

In considering the emergence of the global urban studies, it should be pointed out that in the sense of linguistics its problematics began with the sociological approach development. This approach to the analysis of the environment structure of the city, of the social connections and relationships in it was developed in the writings of prominent persons in 


\section{Chicago School R. Park and E. Burgess.}

The ideas of the French school of "new urban history" (Fernand Braudel) and the English school "comprehensive local studies" (Charles Phythian-Adams) were favourable for urbanistics.

I.M. Grevs and N.P. Antsiferov laid methodological grounds for an integrated approach to the study of cities in Russian urbanistics based on the classical tradition of urban studies (K.I. Arsentiev, V.P. Semenov-Tyan-Shanski and others). Among Russian researchers of urbanization processes A.S. Sieniawska, E.V. Saiko stand out; in addition to the traditional regional ones, there are works created in line with the "new local history". Approaches related to the study of urban everyday life are actively developing.

However, the city language issue has not been comprehensively studied and there are considerable "gaps" related to the study of specific cities. In modern Kazakh linguistics, urbanistics is a relatively young trend. Research in this area which is available today mainly relates to the city language landscape formation issues. The work by T.T. Kotlyarova is devoted to some onomastic environment of Astana formation issues (Kotlyarova, 2008); onym semantic issues are considered in the article by V.I. Suprun (Suprun, 2012).

The study of the general cultural landscape of the city of Pavlodar is new for Kazakhstan urbanistics as a part of the republican project under the aegis of Ph.D., Professor G.S. Suyunova allowing to analyze the cultural-onomastic system of Pavlodar as an existential and scientific phenomenon.

The relevance of the project is determined by the need in systematic study of the regional philological landscape, as the system of Pavlodar names-urbonims as such has not been studied, as well as there is no systematic description of the literary landscape of Pavlodar. Addressing these research subjects will allow studying and describing Pavlodar language and literary landscape from a scientific point of view. The novelty of the research is undeniable: for the first time the scientific research system scope includes onomasiological system of Pavlodar and discusses the literary local history materials that have not been previously considered as an independent object of study in the Kazakh and Russian philology and literary studies.

In the course of this research, the first systematic research of the philological landscape of the city of Pavlodar will be carried out, including literary onomastics and literary urban system description.

The purpose of this article is to present sociological and linguistic theories and trends in the study of the urban phenomenon, as well as provide an overview of the methodological tools of philological urbanistics.

\section{Literature Overview}

The research in the field of philological urbanistics is based on solid research in the field of sociology, philosophy, urbanology, etc. To proceed with philological research methods analysis one should consider the sociological and philosophical background for the emergence of a new trend.

To make the description of investigation degree of the concept of "city" more convenient, we applied the classification of approaches proposed in the work by M.L. Palamarchuk (Palamarchuk, 2009). We considered five main theories, according to which the city is positioned as a natural center of the people's territorial integration (ethno-territorial theory), in this respect the city was considered in the works by many authors, from antiquity by Plato and Aristotle to our compatriots I.M. Grevs, G.M. Lappo, L.V. Kaganski, D.N. Zamyatin; a political and administrative control center - the theory of Oriental despotism (K. Bucher, S. Stam, G. Childe) and the city-states (U.V. Andreev, E. Kirsten); a strongpoint, protective structure - "burg theory" in this direction the French École des Annales (Fernand Braudel, J. Le Goff, J. Duby) and national historical science (E.V. Gutnova) were actively working; division of labor depending on environment: viewed in this way the city is represented in the works of E. Durkheim, W. Sombart; a new form of society integration and new communication environment is a sociocultural theory. The founders of the sociocultural approach are considered to be $\mathrm{M}$. Weber followed by L. Mumford, L. Koshman, A.A. Vysokovskyy, dissertations by E.Y. Ageeva, E.V. Miklyaeva. Culturological interpretation by M.S. Kagan is close to sociocultural approach: the city in his understanding is a meaningful environment. The arguments by G.Z. Hagan, M.N. Mezhevich, E.V. Sokolov support this theory.

There are other trends in the urban study. In sign theory, the city serves as a text which requires reading. Semiotic approach can be traced in the work of Y.M. Lotman (Lotman, 2010). Studies of N.A. Aitov, A.S. Akhiezer A. Bystritskyy, V.V. Vagin, L.A. Zelenov, O.L. Leibowich, S.V. Pirogov, F.S. Fayzullin are significant as well. Social and cultural environment issues of the city were studied by E. Giddens, V.L. Glazychev, H. Lefebvre, J. Ortega y Gasset; in different sociocultural aspects the city is revealed in the studies of A.V. Belikova, N.S. Galushina, A.A. Dregalo, N.V. Dulina, M.V. Korchinskyy, V.I. Ulyanovskyy, T.I. Chernyaeva. Not least important are the issues regarding the nature of modern information society presented in the writings of Daniel Bell, Y.V. Zatsepilin, M. Castells, G.M. McLuhan, P. Taylor. An integrated approach to urban issues in domestic science was proposed in the works of N.I. Gorin, M.S. Kagan, 
A.A. Neshchadin, E.V. Saiko and B.A. Uspenski and in dissertations by G.V. Gornovaya, O.B. Simonova.

L.G. Skulmovskaya grouped urban theory according to the concepts of modern foreign researchers (Skulmovskaya, 2004). According to the author, the works of Chicago school academicians R. Park and E. Burgess (Burgess, 1925; Burgess and Park, 1926) form the basis of the core classical urban theory. They analyzed various aspects of social environment influence the human, biological and economic factors of human life. This resulted in the formation of social development idea (invasion, succession), the "concentric zones" technique. Within the Chicago sociological school Louis Wirth explained the notion of "urbanism" based on its four characteristics: size, city territory, the density and heterogeneity of the population (Wirth, 2005).

The concept of "city" was studied by Max Weber, the author of "understanding sociology" (Weber, 1922). He suggested that the city contributes to the development of individual personality traits, and that it is a tool of historical change. The American scientist L. Mumford stated evolutionary transformations occurring with the cities of Western Europe throughout the history of their development (Mumford, 1970). The modern urban sociology founders are also $\mathrm{E}$. Durkheim and G. Simmel. Durkheim recognized the city as a live integrity, which is characterized by different modes of interaction between people, by deviant behavior (Durkheim, 1924).

Ratio of feminism and urban environment ideas is covered in the works of D. Wolfe, J. Valentine, A. MacRobbie (MacRobbie, 1991), E.A. Pushkareva, Yu. Belozerova and E. Omelchenko (Omelchenko, 2001). In contrast to the Chicago school with the idea of monocentric city, Los Angeles school, headed by Mike Davis, and its theory of "urban militarism" and the notion of the city as a model of polycentric development is gaining popularity.

Western writers reviewed urban environment comprehensively, having created a research base for the national school of urban studies. Within its framework, the features of the city as a sociocultural phenomenon in general should be taken into account. Among the classics of domestic urban studies sociocultural trends were considered by N.P. Antsiferov and I.M. Grevs. Charles Landry believes that creativity of the city is formed by the power of thinking and ideas of the citizens that shape their worldview as well as the perception of culture as a creative resource (Landry, 2006). "For I.M. Grevs and P.N. Antsiferov a city is a real collective identity, collective subject" (Chamkin, 1997). E.V. Saiko states that "the city since its genesis has been formed as a sociocultural process (integrating social networks and accumulating cultural and intellectual potential of society, human) of urbanization as a permanent component of formation and development of certain sociality" (Saiko, 1995), and this is also its phenomenon.

Philological researches originate from the stages of philosophical understanding of the phenomenon of the city. A.A. Svanidze believes that the city is an active source of the historical process due to its concentration, heterogeneity and diverse communicativeness (Svanidze, 1995).

It should be noted that learning the language of the city, and onomastics as a whole as an independent direction consolidates its position in philological disciplines, forming a terminological apparatus and a system of the method so far. However, today we can speak of a methodological tool that enables to carry out comprehensive scientific researches.

\section{Methods}

In preparing the article the following scientific methods were used: descriptive, systematic method and procedures of general scientific systematization, classification, generalization. The descriptive method involves observance of certain requirements: clear understanding of the subject matter chosen, description sequence, ordering, grouping or classification, material characteristics (qualitative, quantitative) in accordance with the research objectives.

Methodic tools for philological urbanism are quite diverse. The choice of its methods can be determined by the object of study, to which we refer the language of the city in terms of its functioning in the urban communication processes. In general terms, we can speak about communicative environment of the city, being formed by a variety of phenomena and processes. For example, philological urbanism today refers to the analysis of onomastic environment of the city as well as its cultural component, within which regional literary works are analyzed. During such an approach actual description of the urban cultural landscape takes place, which requires wider use of the encyclopedic approach to urban studies.

We can highlight two groups of urban philological methods: 1) general scientific and 2) linguistic ones.

General scientific methods are represented by the following kinds:

Systematic approach is used to analyze and synthesize theoretical and empirical material, as well as for development of a model and recommendations. Systematic approach allows revealing the structure and relationship of all urban parts as a system.

The dialectical approach is used to analyze and synthesize theoretical and empirical material, as well as to develop recommendations. The dialectical approach allows addressing the causes of social contradictions characteristic of urban 
life as a sociocultural body.

The generalization approach is required throughout the study for the formulation of conclusions, reports, and theses. This approach allows us to generalize and systematize the study of theoretical and empirical material.

The induction method is used to study the induction of theoretical and empirical information at all stages of the research. Induction provides the transition from the individual facts to general provisions.

The method of deduction is used in the study of theoretical and empirical information at all stages of the research. Deduction enables to make the transition from general to specific provisions of the findings and phenomena.

Statistical method is widely used in studies on urbanistics; its content is diverse and ranges from counting the number of nominations and selection of the most common of them to describing the statistical organization of the whole onomastic class and laws of its development.

\section{Linguistic Methods Used in Philological Urban Studies}

The historical method is specifically important when referring to onomastic material, since the appearance and the whole subsequent history of proper names are directly connected with the history of society and its economic, political and cultural life. We also plan to carry out the analysis of onomastic vocabulary from the historical perspective, using two ways if necessary: 1) from the past to the present state (prospective approach) and 2) from the present to the past (retrospective approach).

Comparative-historical method in urban studies reveals the general and the specific in historical phenomena, the unity and diversity of the historical process, which helps to understand the true essence of history. The comparative method is used at all stages of the research in collecting, studying and systematization of theoretical and empirical sources on this issue, analyzing materials, writing texts on the subject of the study. It also allows comparing approaches, theories and concepts developed by various researchers, and making their analysis and evaluation, comparing the sources of the data.

The application of comparative method is perspective for our study. Diverse phenomena of the plane of content (types of onomastic objects nomination, semantic models of onyms, motives for naming, etc.) and plane of expression (onym structure, their derivational structure, grammar, phonetic and accentual indicators) are subject to comparison.

Semiotic method enables to qualitatively represent linguistic component of urbanistics. For example, the category of objects of the general cultural landscape can be considered carefully in view of the set of characters (onyms) and their differentiated characteristics, methods of their linguistic expression (in the sounds, morphemes, words, word combinations), specific manifestations of systemic relations in determining the level of onomastic material consistency.

In the description of the urban studies material one might use separate linguo-culturological methods, including traditional methods of ethnography and methods of experimental cognitive linguistics, with native speakers (informants) being the most important source of material.

Historical and genetic method is used at all stages of research to analyze theoretical and empirical data. This method allows analyzing the processes of language transformation of the city, variety of names, the onomasticon in general.

Content analysis allows obtaining conclusions about the state and properties of social reality by analyzing the content of texts on the subject. It is necessary for statistical information analysis and data sources at all stages of the study. Content analysis makes it possible to thoroughly explore the selected materials from a quantitative point of view.

One of the important methods of linguistic urbanology is the method of associative experiment (AE). Associative experiment is a technique aimed at identifying associations prevailing in previous experience of an individual. Psychological dictionary defines associative experiment as a special method for studying a person's motivation (Zinchenko, 1996). Primarily, AE method is used in the study of onomastic consciousness.

Generally, there are three types of association experiments:

- free association, in which subjects are asked to answer using a word - R, the first to come to mind at the word presentation - S, with no loss of any formal or semantic features of the word - R;

- directed association, in which the experimenter to some extent limits the selection of hypothetic R, by imposing certain restrictions (e.g., responding only with nouns, etc.);

- chain association, in which subjects are asked to respond to any number of words - $\mathrm{Ri}$, first to occur at the word presentation - S, with no loss of any formal or semantic word features.

The following groups of methods were used:

The integrative nature of philological urbanistics explains the widespread use of interdisciplinary methods originating from other sciences - anthropology, sociology, political science, psychology, etc. 
Interdisciplinary methods allow the use of instruments related to socio-economic sciences and humanities, which makes it possible to consider the city as a social and cultural phenomenon.

The typological method involves allocation of types as ideal models, reflecting some of the essential features of a certain set of phenomena, but deliberately ignores other signs considered in this case as irrelevant. This method allows exploring the aggregate of the urban life phenomena of the same order as a kind of integrity regarded as a closed system.

The logical method is used throughout the study to identify the laws and the conclusion statements. This method enables to reveal the regularities of the urban community formation in its logical consistency.

For the study of the literary component as part of urban cultural life philological urbanistics uses methods of literary analysis and, above all, a comprehensive analysis of literary works. It consists of three stages.

The first stage of the analysis is based on the principle of historicism and includes a choice of starting position for the analysis carried out on the basis of analyzing ideology and theoretically in view of the author's worldview. At this stage, the concept of the work is pre-formulated, which will confirm or deny further investigations. Review of the history of the creative work, drafts, different editions and versions helps to identify changes in the concept of the product, storylines modifications, and composition transformation.

The second stage involves consideration of external relations of the work. Traditionally, the first to be considered are sociological connections of the work (due to historical, social, political and economic conditions that gave rise to certain peculiarities of the work). Next to be considered is the connection of the work with the biography of the author, the events of his personal and public life. Further on, culturological links of the work are set out, which is particularly important for the description of the city cultural landscape.

The third stage is devoted to the analysis of internal communications of the work, the structure and meaning of the text itself. At this stage, the division of text elements and review of each of them takes place, enabling to see the text as an organized plurality, as a system of techniques determined by the artistic design unity.

\section{Results}

The article describes a number of questions on the issue of methodological base of philological urbanistics. In particular, it provides an overview of the problematics of its formation, development and application of methods for urban analysis. The authors come to the conclusion that the methods of linguistic as well as of interdisciplinary character may be put to active use which is associated with the multidimensionality of the object of urbanistics itself, the city as a form of organization of people.

Understanding the city, its linguo-cultural and communicative environment is extremely important for the philological urbanistics. The adequacy of the methodological basis of such research is essential for their scientific consistency.

\section{Discussion}

The content of the present article was discussed at a scientific seminar of the Department of Russian Language and Literature of Pavlodar State Pedagogical Institute (Kazakhstan). Moreover, some of the problems have been outlined by the authors in the materials of the international scientific conferences and in journals recommended by the Committee for Control of Education and Science, Ministry of Education and Science of the Republic of Kazakhstan.

\section{Conclusion}

Philological urbanism today is a rapidly developing area of onomastics that separated from the latter by virtue of having an independent object of research, a broad and original aspectology, own methodological and procedural framework. We have formulated the conceptual and terminological apparatus of urbanistics, developed urbonim typology, and studied the problems of onomastic consciousness. All this is observed in the Russian urbanistics, which is not the case in urbanistics in Kazakhstan. Lack of systematic research in the field of urbanism in the country makes it relevant and promising in the context of the aforementioned research project under the aegis of Professor G.S. Suyunova. In the course of the project fulfillment, the first systematic study of philological city landscape will be carried out in the republic.

Full disclosure of the problem with the tools of philological urbanistics cannot be done in the framework of an article given the broad nature of the subject. Therefore, further work of the authors will be continued and developed in the course of research on the description of the overall cultural landscape of the city. 


\section{Acknowledgement}

The article was supported by the grant of the Ministry of Education and Science of the Republic of Kazakhstan (contract No. 290 of 02/12/2015) for "Fundamental and applied research in the human sciences."

\section{References}

Burgess E. (1925) The growth of the city: on introduction to a research project. Chicago.

Burgess E., Park R., McKenzie R. D. (1926) The city. Chicago.

Chamkin, V.F. (1997). Teoreticheskie osnovy urbanistiki v rabotah Grevsa I. M. i Anciferova P.N. / Russkij gorod: istorija, ljudi, kultura. Materialy mezhregionalnoj nauchno-prakticheskoj konferencii. Chast I [Theoretical Foundations of urbanity in the works of Grevs I. M. and Anciferova P. N. Russian city: the history, people and culture. Materials of inter-regionale scientific-practical conference. Part I]. - Ryazan, (P. 22) [in Russian]

Durkheim E. (1924) Sociologie et philosophie. Paris: Alcan.

Frumkin, R.M. (2001). Psiholingvistika: Uchebnik dlya studentiv vysshih uchebnih zavedenii [Psycholinguistics: Textbook for students of higher education institutions]. - Moscow: Academy, (P. 320) [in Russian]

Kotljarova, T.T. (2008). Onomasticheskoe prostranstvo novoj stolitsy Kazahstana // Psihologija. Sociologija. Politologija [Onomastic space of the new capital of Kazakhstan // Psychology. Sociology. Politics]. - № 8, (pp. 8-13). [in Russian]

Landry, C., (2006). Kreativnyj gorod [Creative city]. - Moscow: Classic - XXI, (P. 26) [in Russian]

Levitsky, V.V. \& Sternin I.A. (1989). Eksperimentalnye metody v semasiologii [Experimental Methods in Semasiology]. - Voronezh [in Russian]

Lotman, Y.M. (2010). Semiosfera [Semiosphere]. - St. Petersburg: Iskusstvo, - (P.704) [in Russian]

MacRobbie A. (1991) Feminism and youth culture. - Basinstoke: Macmillan.

Mumford L. (1970) The myth of the machine. - New York.

Omelchenko, E. (2000). Molodezhnye kultury i subkultury [Youth culture and subculture]. - Moscow: Institute of Sociology [in Russian]

Palamarchuk, M.L. (2009). Gorod kak sociokulturnyj fenomen/Dissertatsija kandidata filosofskih nauk [City as a social and cultural phenomenon/ dissertation in Philosophy]. - Arkhangelsk, (P.134) [in Russian]

Saiko, E.V. (Ed.) (1995). Gorod kak sotsiokulturnoe yavlenie istoricheskogo protsessa [The city as a sociocultural phenomenon of the historical process] Edited by- Moscow: Nauka, (P. 20) [in Russian]

Skulmovskaya, L.G. (2004). Gorod v prostranstve kultury regiona: obshhee i osobennoye [City in the cultural space of the region: general and special]. - St. Petersburg: INFO, P.160. [in Russian]

Suprun, V.I. (2012). Onimicheskaja semantika i ee specifika [Onimicheskaya semantics and its specificity]. - Vestnik of KazNU, № 2., (pp. 96 -101) [in Russian]

Svanidze, A.A. (1995). Gorod v civilizatsii: k voprosu opredeleniya // Gorod kak sotsiokulturnoe yavlenie istoricheskogo protsessa [City in civilization: a question of definition // City as a sociocultural phenomenon of the historical process]. - Moscow: Nauka, (pp. 29 38) [in Russian]

Weber M. (1922) Die Stadt. - Wirtschaft und Gesellschaft, Kap 8. // Grundriss der Sozialekonomik. III. Abt. Tubingen.

Wirth L. (1924) Urbanism as a Way of Life // The American Journal of Sociology. Chicago.

Wirth, L. (2005). Urbanizm kak obraz zhizni [Urbanism as a lifestyle] / Izbrannye raboty po sociologii [Selected Works in Sociology]. Moscow: INION RAN, (pp. 93-118) [in Russian]

Zalevskaya, A.A. (1979). Mezhjazykovye sopostavlenija v psiholingvistike [Interlingual comparison in psycholinguistics]. - Kalinin [in Russian]

Zinchenko, V.P. \& Meshcheryakov B.G. (Eds.) (1996). Psychological Dictionary. 2nd ed., reviwed and added. - Moscow: Pedagogika Press, (P.440) [in Russian] 